\title{
Capitalism and Corporate in Lampung Local Politics
}

Komunitas: International Journal of Indonesian Society and Culture 11(1) (2019): 22-31

DOI:10.15294/komunitas.v11i1.13161

(C) 2019 Semarang State University, Indonesia p-ISSN 2086 - 5465 | e-ISSN 2460-7320

http://journal.unnes.ac.id/nju/index.php/komunitas

\section{JOURKALS}

\section{Robi Cahyadi Kurniawan ${ }^{1}$, Dedy Hermawan², Himawan Indrajat ${ }^{3}$ Budi Kurniawan ${ }^{4}$}

1,2,3,4Social and Political Science Faculty, University of Lampung , Bandar Lampung, Indonesia

Received: January 31, 2018; Accepted: March 1, 2018; Published: March 30, 2019

\begin{abstract}
State and company / corporation in the context of governance are two of the three fundamental pillars of democratic development in addition to the market. The relation of both, in the context of Lampung's local politics is object to study, in particular the company /SGC. This research was conducted in May 2014. The study used a qualitative research type, which saw most of the intrinsic social life, with in-depth interviews with personalities and selected informants. The approach used in this study is the approach of critical social science (CSS), which saw social science as a process of critical inquiry phenomenon. The results showed that in Lampung local election at 2014 ago, there were strong relations between the corporation / company in the case of the Sugar Group Company (SGC) in the Lampung Governor candidates. SGC is serving as a source of funding for the campaign of the election for the last governor election in 2014. SGC does it as a way of business development.
\end{abstract}

\section{Keywords}

state; corporations; local politics of Lampung

\section{INTRODUCTION}

Based on Law No. 232014 explained that the local government given the authority to regulate and manage the household affairs, in other words that the local government have the authority to take care of their own governmental affairs and interests of local communities own initiative based on the aspirations community in the system of the Republic of Indonesia.

The authority to take care of his own government, for regional leaders is a challenge. The democratization process which is prominent in the implementation of postconflict local elections, both the regional election, is a place to prove whether the region is able to take care of itself without the intervention of other parties.
Other parties in this case are parties outside the state who have interests in the form of political or economic and social interests that can intervene in the authority and authority of the State (region). The implementation of the Governor of Lampung Province election was a venue for fighting political, economic and social and cultural interests in Lampung.

On the other hand, the researcher has a suspicion that there is a correlation between SGC companies and loca politic in Lampung, Lampung Governor election in 2014 . This condition has become very interesting from the point of view of eco-

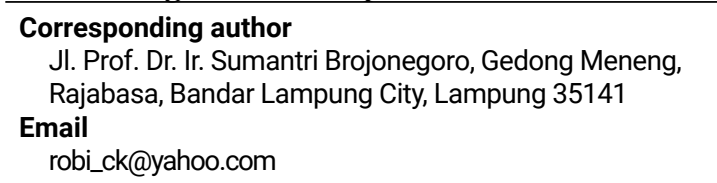


nomic (capitalism) politics. What is the interest of SGC in Lampung's local politics, especially in the election of the Lampung Governor ? What economic benefits did SGC get in the election of the Lampung Governor?

\section{METHODS}

This study uses a type of qualitative research. Researchers a $\mathrm{n} \mathrm{k}$ ualitatif viewedmostsociallifewithintrinsic.Accordingto Lawrence Neuman (2006, p.157),qualitative research is :

"Qualitative researchers use a language of case and context, employ bricolage, examine social processes and their social contexts, and look at interpretations or meaning settings. They look at social life from multiple points of view and explain how people construct identities. Only rarely do they use variable or test hypotheses, or convert social life into numbers ."

Most studies use grounded theory . This is what makes research have flexible and more interesting data. According to See Harper and Schwandt in Lawrence Neuman (2006, p.15), qualitative research remains open to change, qualitative research is willing to change the direction or focus of research projects and may leave their original research questions in the middle of their research projects. Case studies according to Neuman (2006, p.40) can be done by individuals, groups, organizations, interest groups, events, or units based on geographical location.

The approach used in this study is the Critical Social Science (CSS) approach . Critical Social Science (CSS) approach . This approach was aimed at Karl Max (1818-1883) and Sigmund Freud (1856-1939), and was described by Theodor Adorno (1903-1969), Eric Fromm (1900-1980), and Herbert Marcuse (1898-1979). In general, Critical Social Science (CSS) sees social science as a critical process of inquiry that goes beyond the illusion of revealing real structures in the world with material to help people change conditions and build a better world for themselves ( Lawrence Neuman , 2006, p.95) .

The data sources in this study come from polymer data and secondary data. Secondary data in this study comes from the materials library support and or information obtained through a third party that is considered to be related to the problem under study, such as books, regulations and documents.

\section{DISCUSSION}

\section{Study of Capital Strength in Indonesia}

The initial study of the power of capital in Indonesian politics was pioneered by Richard Robinson. Richard Robinson is one of the most famous authors of the book "The Rise of Capital " in 1986. The book " The Rise of Capital " has a very big influence on the political and economic development of Asia as well as the economy - politics in general. In addition, the book " The Rise of Capital " also plays an important role in changing the focus of Southeast Asian and Indonesian studies from behavioral approaches (Behavioralism ), the world system ( world system ), and dependencia theory towards the approach of political economy in 1980 (Vedi R Hadiz, 2013, p.3). The book " The Rise of Capital "succeeded in putting the economic - political position as the heart of the study of Indonesian politics and society.

Richard Robinson's main achievement was succeeded in putting the economicpolitical position as the heart of the study of contemporary Indonesian politics and society. This was done through an analysis of the formation of the modern Indonesian bourgeoisie and the significance it made. The peak of Soeharto's New Order authoritarianism in running the Government, was the main focus of the analysis. Ironically, the modern bourgeoisie was not found among the petty bourgeois traditionalMuslims . Because bourgeois traditional Muslims are people who have influence before the zoth century. Traditional bourgeois Muslims also often demand the protection of the State of Indonesia at the beginning of the emergence of Indonesian Nationa- 
lism. This is in accordance with the opinion of Richard Robinson in Vedi R Hadiz (2013, p. 3):

"Such a bourgeoisie is in another place in the growth of conglomerates run by ethnic Chinese rulers and some families that hold bureaucratic power and are closely connected with the conglomerates. In addition, the presence of the new bourgeoisie does not always have implications for the emergence of "Bourgeois Democracy" or the kind of free market economy the neoclassical economists covet. "

In 1986, Richard Robinson did not see the State as an instrument of the capitalist class. But this does not rule out the possibility that the situation will occur in the future. This is consistent with the statement of Richard Robinson in Edward Aspinall (2013, p. 21):

"One of the more interesting questions related to social and political change in the third world is whether the capitalist society directed in this country is a new historical model that will last long or just pause. Will they be firmly planted and mature when capitalism expands and becomes stronger or whether they will submit to the power of the bourgeoisie when the capitalist class grows. Perhaps the main work of the State of Indonesia since 1949 was to provide all the requirements for capital accumulation and interference in various disputes between different and competing elements of capital. State autonomy and itsofficials are closely related to the progress of the capitalist class in Indonesia and the dominance of foreign and Chinese elements. “

Thus, we can see that foreign and Chinese capitalists have a close relationship with political power. Indirectly, foreign and Chinese capitalists exercise political power.This also provides space for a country that is strong as a mediator and helps provide a precondition for the growth of capitalism. Ironically, in a Capitalist country the place for the (capitalist) capitalist class is almost non-existent. So this requires the "native" Capitalist class to appear independent. However, the "indigenous" capitalist class did not appear organically from the traditional
Islamic petty bourgeoisie. On the contrary, the "native" capitalist class is born of families of bureaucratic politicians who control the State and its allies. Thus, capitalists are born at the same time as the power of the State and are in opposition to the State (Richard Robinson in Edward Aspinall 2013, p. 22).

According to Richard Robinson in Achmad Choirudin (2013, p. 124), Dutchowned trading companies were nationalized then joined to form "the big eight" and obtained a monopoly on the import of thirteen commodities, including 9 basic necessities of life. They control 70 percent of the imported commodities in Indonesia. Meanwhile, BUMN (State-Owned Enterprises) managed to dominate the national economy. The state controls the movement of domestic private capital through the Association of Private Entrepreneurs and Private Entrepreneur Organizations. The New Order government also formed the National Consultative Body as the official channel for coordination between business people and their representatives.

Richard Robinson built the thesis that State capitalism is not only a complement to private capital but also a sign that the emergence of State capital. Thus giving rise to various contradictions. First , State capitalism has increasingly strengthened the bureaucrat's capitalist position. Second , the strengthening of patrimonial patterns and the limited amount of capital accumulation owned by indigenous people. Third , the birth of the Chinese capitalist class which has accumulated capital with a very solid foundation. Suharto established intimate relations with capital groups. Soeharto became the servant of the ruler of capital for his personal interests, power and cronies. Soeharto and capitalism have merged into one in the connection of capital and bureaucracy. Thus giving birth to political families and giant conglomerates whose position cannot be determined by an abstract market mechanism. Rather, it is a connection with a system of patronage under Suharto. During the Soeharto era, the support of the internal State Government system then 
formed a system of domestic capitalism (Richard Robinson in Achmad Choirudin, 2013, p. 126).

Soeharto has collaborated with capital owners. This can be seen from the business maneuvers of Chinese people. Liem Sioe Liong is a Tipan instant noodle that is known to be very close to Suharto before becoming President. Even in the writings of Robinson (Robinson in Achmad Choirudin, 2013, p. 126), he became one of the suppliers of food, clothing, weapons, when the Dutch began entering Central Java. The proof, all kinds of business needs Liem Sioe Liong made easier when Suharto became president. Now Liem Sioe Liong has large companies, such as PT. Mega (Clove in 1966), CV. Waringin, PT. Bogasari Flour Mils (Flour Mill), PT. Indofood (Food), and PT. Indocement.

Based on Richard Robinson's observation , the evolution of capitalism that occurred in Indonesia can be seen from 3 (three) stages. First, survive in the fortress period and guided economy. At this stage, capitalism was difficult to move because of the strong influence of guided economic policies under the Old Order. Second, the New Order took power and tried to build a private business group. Third, new capitalist groups that have full political support from the New Order.

The study of capital strength was also carried out by Dr. Yahya Muhaimin. Yahya Muhaimin was born on May 17 in Brebes, Central Java. Yahya Muhaimin holds a bachelor's degree from Gadjah Mada University and a Doctorate from Massachhussets Institute of Technology. The results of Yahya Muhaimin's writings have always been a reference for Gadjah Mada University Students and Lecturers. The book "Indonesian Business and Politics " is a dissertation of Yahya Muhaimin while taking a doctoral degree at Massachhussets Institute of Technology (MIT), Cambridge, United States. However, many parties consider the book "Indonesian Business and Politics “ to be a duplicate result. Yahya Muhaimin allegedly duplicated the book " Capitalism and the Bureaucratic State in Indonesia " by

\section{Richard Robinson.}

In addition, Andrew Mcintyre also seeks to explain business in the implementation of Democracy. Andrew Mcintyre is a Professor of Political Science at ANU. According to Andrew Mcintyre in the book "Indonesia: Democracy and the Promise of Good Governance " (2007, p. 108) democratic politics and decentralization of new Indonesia creates different opportunities and constraints for them in politics. Along with the increasing demand for business with the implementation of democratization. Thus, the Government actively discriminates which demands competition.

The last post-New Order study of the power of the oligarchic authority of capital was carried out by Vedi R. Hadiz and Richard Robison (2004) from Murdoch University, Perth, Australia. As we know that Richard Robinson has contributed brilliant ideas to the Indonesian people.

According to the book 'Reorganising Power in Indonesia' by Vedi R. Hadiz and Richard Robinson (2004, p. 147), Suharto led the Indonesian State triumphantly and invincibly. However, the seeds of destruction immediately destroyed Suharto's glory. The financial crisis that hit Asia in 1997 and 1998 left a legacy that undermined Indonesia's financial condition. The Indonesian economy, which has enjoyed spectacular growth rates for more than two decades, found itself quickly confronted with insulting rapid economic reserves as its currency entered a prolonged decline that lasted more than four years.

The Indonesian government then seeks to protect the shift in its currency. The Indonesian government contacted the IMF on October 8, 1997. Then the Indonesian Government requested \$ 43 billion in rescue assistance. This was announced on October 31, 1997 (Richard Robinson, 2004, p. 155). In return, the IMF began to change the direction of the Government faced with fiscal disasters and increasing debt (Richard Robinson, 2004, p. 158). Not only that, the State no longer plays a role to protect conglomerate families. Even States are forced to move against them and confiscate their ass- 
ets and enforce debt payments in order to protect their own fiscal position. So that it closes the possibility of the entry of foreign capital into Indonesia.

Marx and Engels rejected both the liberal state theory and the state theory that Hegel's philosophy had. On the contrary, these two thinkers emphasized conflicts of interest at the community level as a determining factor. Conflicts that occur in the community will result in the power of the dominant social class. Where the dominant class has a greater ability to control the State. Therefore, States tend to choose to side with one class. State alignments according to Eric Hiariej (2003, p. 279 ) need tobe understood in 3 (three) ways, namely:

a. The alignment of the dominant class is a difficult consequence that is inevitable because this social class often occupies the most strategic position for the sustainability of economic development.

b. Dependence on the health of the economy often forces States to take actions that might be contrary to the dominant class.

c. The active role of this country is increasingly important when the dominant class which should take a leading role in the process of capital accumulation is not sufficiently economically prepared or politically capable enough, for example to control the subordinate class.

\section{STATE CAPITALISM}

According to Eric Hiariej (2006, p. 93), the role of the State as an agent of development can be seen in two ways. First, the State participated directly participate in capital accumulation by the way has the financial resources and growing capital in various business sectors through state enterprises. Second, the State participates indirectly through planning, regulation and implementation of policies.

According to Eric Hiariej (2006, p. 95), state companies have positions in the structure of the Indonesian economy. Sta- te companies play an important role in controlling business sectors which include the production of natural resources, infrastructure, manufacturing, banking, and distribution of basic necessities. In addition, state companies also have influence in other sectors such as trade, agriculture, sea, air and construction transportation. According to Robinson in Eric Hiariej (2006, p. 95), the same companies also play a role as the main partners of foreign companies in conducting production and investment. So, companies included in the natural resource sector are Pertamina, PT. Timah, Aneka Tambang, and Inhutani.

"State companies engaged in the manufacturing sector are also in crucial conditions. The New Order not only strengthened its position, but also expanded its role in producing capital and semifinished goods. This causes state companies in the manufacturing sector to grow larger and more capital intensive than private companies.In addition, the State also participates in planning and developing an adequate regulatory framework for economic development. In many ways, government regulation protects the capitalist class from free competition and penetration of foreign capital. In addition, the State also finances domestic businessmen through various rules that distribute subsidies, credit and projects “(Eric Hiariej, 2006, pp. 95-96).

According to Robinson in Eric Hiariej (2006, p. 103), fiscal difficulties are not a barrier for sectors related to natural resources and other domestic sectors such as automotive and petrochemicals. Sharing monopoly rights, contracts, concessions and credit is a custom carried out by the State. The most controversial monopoly rights were awarded to the Clove Marketing and Support Agency (BPPC) in order to buy and sell Indonesian farmers' cloves.

The New Order government made efforts in order to free the movement of foreign capital. This is seen in different reform policies. The first reform policy was aimed at facilitating international lending procedures which included replacing special restrictions on foreign loans with daily restrictions, 
short-term capital inflows, protection from the risk of foreign exchange and subsidizing foreign commercial loans (Nasution in Eric Hiariej, 2006, p. 105). The second reform policy, related to capital market deregulation that occurred in 1987 and 1988. It aims to revive the JSE as an alternative funding source . The following are some of the ways in which capital market reforms have benefited the big class (Rosser in Eric Hiariej, 2006, p. 105) "High-class capitalists benefit from capital market reform in three ways,:

a. They get cheap access to international portfolio capital.

b. They can expand their business into new industrial areas related to the capital market.

c. Big business people also have the opportunity to diversify their ownership structure "

For the past 30 years the country has played a decisive role in economic development and protecting capital owners. In this case, the State continues to perform an important function as a provider of a regulatory framework that allows free markets to work optimally. This important function relates to policies to guarantee fiscal discipline, reduce public spending, tax reform, financial liberalization, encourage competitive exchange rates, liberalize trade, launch foreign investment, privatize state enterprises, deregulate the economy, and protect property rights (Eric Hiariej, 2006, p. 116).

\section{Capitalism in Indonesia}

When we compare, the condition of the Indonesian capital body at this time is different from the condition of the Indonesian capital body when Richard Robinson wrote the book "The Rise of Capital" in 1986. The relationship of capital to the State and its political implications is also different. So, let's examine some important changes and sustainability in the body of Indonesian capital (Edward Aspinall, 2013, pp. 24-28 ), are as follows; Private capital is now much stronger when compared with twenty-five years ago. One of the reasons is the dramatic change in the State of Indonesia's revenue base. Thus, the Indonesian state is very de- pendent on private business when compared to the previous period.

Second point, some of the structural characteristics identified by Richard Robinson as a barrier to liberal reform still remain and have had an influence to date. The separation between Chinese capital and "native" capital remains a very important thing. In addition, Chinese people still dominate private business land. The thirdpoint is that the rise of the "indigenous" capitalist class is far more powerful exactly as anticipated in the book "The Rise of Capital". The country's protectionist policies have given birth to big business people since the 1970s. The businessmen were also born directly from the politico-bureaucrat elite. Points fourth , the birth of local businesses or regions on the political stage. This is not anticipated by Richard Robinson in the book "The Rise of Capital". So that the local capital sector is the party that gets the most benefits from democratization and all the political reforms that accompany it. On the other hand, the local capital sector is also the most disadvantaged if there is a muscritarian regression.

The fifth point, finally, is that other important capital sectors that became the focus of Richard Robinson in 1986 experienced a very significant change in number. At present other capital sectors have very little weight and influence. Ironically, the stateowned business and military business also declined. This is precisely inversely proportional to the increasingly successful business of the private sector.

The new land for capital growth began to mushroom in Indonesia after deregulation in various fields. Although there has been a commodity boom for more than a decade. At present, the growth of capital investment in the mining business sector is still very insignificant compared to the Soeharto era. Following are the statements of Hill and Prateek Tandon in Edward Aspinall (2013, p. 28) :

"During the Soeharto era, Indonesia regularly attract investment of more than five per cent of global mining exploration investment, while there are currently only able to attract investment of less 
than o, 5 percent. International surveys of the mining business investment climate (eg the Kananda-based Fraser Institute survey) place Indonesia at the bottom of the world, slightly above Zimbabwe and Venezuela. “

Thus, the presence of foreign investors in the sector has been underestimated by Indonesian capitalists. Indonesian capitalists enjoy greater access to local political power and greater ability of legal processes concerning mining, mining and the like. Apart from the presence of the foreign sector, Domestic Indonesian bourgeoisie is a class that still has many of the features exactly as identified by Robinson in the book "The Rise of Capital" in 1986. Many of the bourgeoisie who managed to regain their lost rights by manipulating a program made by the government to restructure banking liquidity. So, in general, business forces force the Government to bear the burden of their debt (Robert and Hadiz in Edward Aspinall, 2013, p. 29). This statement was later supported by Jeffrey Winters. According to Jeffrey Winters in Aspinall (2013, p. 29), it is stated that after authoritarianism experienced a collapse a "wild oligarchy" was born which could not be disciplined, either by the Soeharto-style sultanate government or strong rule of law or other mediating institutions in Indonesia.

The birth of a stronger domestic capitalist class vis-à-vis International and State capital is an era that may not have marked the victory of capital. In fact, this marks a further stage of capital awakening. Indonesian capitalists are able to adapt very quickly and easily to democratization amid significant threats to capitalism or private ownership. Indonesia's democratic ability to absorb and accommodate the ruling political elite , partly through corruption, and patrionage distribution. Of course this is one of the keys to the success of democracy in Indonesia (Edward Aspinall, 2013, p. 30). Then Philippe Schmitter also has a view similar to Aspinall. According to Philippe Schmitter in Edward Aspinall (2013, p. 31), states that:

" One of the originators of the modern theory of democratization, argues that de- mocratization throughout the world turns out to be much easier than he and other early scholars estimate, precisely because democratization produces very little redistribution or other reforms that might harm the interests of dominant economic elites"

The political theorists talk about the capitalist class which proves itself skilled and flexible in Indonesia. So as to be able to accept new democratic political orders. Entering the new era today, the capitalist class undermines the order from within through the mechanism of "money politics". But this does not indicate that we can see the capitalist class as a driving force for democratization (Edward Aspinall, 2013, p. 31).

During the authoritarian era of the New Order era, capitalism in Indonesia continued to grow. This starts from the role of the roles of the Government and the owners of capital (capital). Relations between the Government and the owners of capital began to appear in 1958. BUMN (StateOwned Enterprises) has an important role in the relationship. BUMN took over several business unit sectors of Dutch-owned companies, such as changes in ownership of 90 percent of plantation products, 6o percent of foreign trade, 246 factories and mines, a number of banks and various types of service industries (Okezone, February 7th, 2014).

\section{Sugar Group Company (SGC) in Lam- pung Local Election}

The results of the study from Ward Barenscout and Purba (2014) need to be looked at in examining the SGC linkages in local Lampung politics, especially in local politic. Ridho Ficardo became the new governor of Lampung Province, the southern province of Sumatra. At first sight, this 33 years old young man seemed a non-permanent choice because he lacked the charisma and experience of the government. But he has a winning feature: he is the son of the directors of the Sugar Group Companies (SGC).

Financial support from Sugar Group allows Ridho to make the governor's election a luxurious achievement. Sugar-filled trucks drove to villages throughout Lampung to 
carry out a 'sugar flood', a large 'flood' of sacks of sugar weighing 2 kilos decorated with pictures of Ridho. Music concerts, puppet dramas, and according to the news, direct distribution of 50,000 rupiah per voter ensured that Ridho's name gradually increased in the polls. In the end, it won $44 \%$ (percent) of the votes, ahead of its competitors. This achievement has costs, according to estimates of observers interviewed, up to 500 billion rupiah (43 million USD).

This money strengthens SGC's considerable political influence. Sugar Group has long contributed to politicians. Since 2011 the company has funded regent election campaigns, which have led to the election of 'their own' candidates in Tulang Bawang and Tulang Bawang Barat.

It is no coincidence that in these districts, there are large plantations owned by the Sugar Group. This company can benefit quite a lot by placing their own people in positions of authority. The main reason for this sugar-intensive waste from Lampung is the coming to an end of the 30-year SCG land rent (HGU) for several plantations. Given that large bribes with renewals such as land leases usually involve, SGC may be able to cover part of the campaign costs now because Ridho will be the person to authorize the extension.

SGC is also involved in a number of land conflicts with other companies, there is a prolonged legal battle with the Salim group over land and a factory and also with villagers. The villagers in Tulang Bawang made a major protest against SGC, because the company grabbed their land and cut off access to their villages in 2012. With the local governor and regent now allies, SGC will not be bothered again by the hassles. It is possible that SGC will use its 'friendly' politicians to obtain licenses to get more land to expand its plantations. The tense nature of land ownership in Lampung does indeed indicate that Ridho's election might also trigger a new wave of land conflict.

Election program lined up at the site indicates that serve Sugar Group is the main objective: "the potential of agro-business in Lampung hampered (...) by weak inf- rastructure, security issues and extortion ('wild charges, which is looking for rental). What are we have to do to solve this problem? We need to choose a leader who has a solution ". Indeed, for SGC, Ridho embodies the solution to another major operational challenge: seeking rampant rent that has plagued this company for years.

Bureaucrats and politicians have extorted money from this company by threatening to take (and make) irregularities in SGC's land use and its production. SGC is the dominant company presence in a remote economic area. He also works within a weak and conflicting legal framework regarding land use. So SGC is vulnerable to being used 'like an ATM' by enterprising individuals at all levels of government. Ridho is now expected to act more decisively in handling these practices. In fact, that was what had been debated by informants who sympathized with the SGC that the SGC gave Ridho the ability to 'clean up' and 'professionalize' state institutions.

While employers needed to establish contact with influential bureaucrats at the time of the New Order, they now buy their influence by supporting political election campaigns or they themselves become politicians. Because of the soaring costs of running election campaigns, politicians cannot sacrifice the company's support. A successful political career requires either being or finding a wealthy businessman.

Businesses recognize that political contact is essential to obtaining licenses and avoiding illegal levies everywhere, they face strong incentives to engage in secret or non-secret agreements with political candidates. These considerations drove the Sugar Group to support politicians. This company does not really want a more professional bureaucracy when issuing new licenses. The bureaucracy that implements universal and fair policies and laws will not allow the Sugar Group to cover the money spent on election campaigns. To cover these costs, Sugar Group expects its politicians to intervene in bureaucratic procedures, namely to bend rules and regulations to their advantage. In this way the agreement weakens state 
institutions and the relevance of rules and policies.

In order to honor their commitment to support and raised funds campaign, the elected leader of continuous damage and avoid bureaucratic procedures. The weakening of state institutions produced further strengthens the dependence of employers on politicians, because they have little guarantee that the rules and policies will be applied in predictable fashion if they do not have political contacts. In that sense, the Sugar Group business strategy is only self-defeating. As long as economic elites (such as the SGC director) use their contacts to avoid regulation, their political interference will not lead to the professionalism of state institutions or eradicate the practice of seeking rent.

The overlap between politics and business also strengthens itself in other ways . Voters see the wealth of coalitions gathered by big business politics by giving permission and contracts to each other. They realize that politicians' promises of changing regulations and policies are often empty, because voters see how elected leaders do not comply with regulations when pressed by their company friends. In this context it is not surprising that many voters trade their votes for money (or sugar), feeling that the sweetener might be the only benefit they can realistically expect from their politicians.

Observation of the campaign during the April $9^{\text {th }}$ at legislative elections showed that voting had become very common. Voters become increasingly pragmatic in their relations with politicians. The irony is that this disappointment with politics and the hopes generated from money and prizes facilitates continued domination of the economic elite, because soaring campaign costs make politicians dependent on wealthy donors.

There is little room for voters to punish politicians involved in illegal deals with companies. Voters generally do not know which companies fund their candidates. Politicians are required to report their campaign funds and costs . But because there is no mechanism for checking their truth, the- se reports have become futile administrative exercises. Furthermore, even though the involvement of Sugar Group in the Lampung governor election was rather blatant, local journalists rarely dared to explicitly name the company because of fear of retaliation and withdrawal of advertisements. As a result, voters don't really know what their business interests might support with his voice. Farmers who protested against Sugar Group in Tulang Bawang in 2012 may have chosen Ridho, only because the role of companies rarely entered public debate. (http:// www.insideindonesia.org/pemilu-lampungyang-berlapis-gula)

Some informants provide important data that the presence of Ridho Ficardo, in Lampung politics is closely related to the Sugar Company Group, because her real father is right-handed Fauzi Toha big boss is Mrs. Lie company based in Jakarta. The interest of Sugar Group in placing Ridho as a candidate for Governor of the party made by SBY, the democratic party is no more and not an effort to secure access to land that will expire the right to use in 2015. On the other hand, to eliminate negative access and demand for money usual development said the previous Regent of Tulang Bawang for the period of 2012; Abdurrahman Sarbini. Most of the funds in the regent election in the areas closest to the land of the Sugar Group company were allegedly from the company made by Mrs. Lie.

This symbiosis of mutualism has long happened since the establishment of the company. The people around the land actually also benefit from the establishment of the company, with better road access and Corporate Social Responsibility (CSR) programs from the company, but because of mistakes made by the local government, the program is sometimes not on target, giving rise to jealousy and social turmoil in the surrounding community. Turmoil increasingly emerged when the 1998 reform took place, with the rise of land tenure by some people or some elements, so that local strong man needed assistance in overcoming it, in this case the head of the region. The most appropriate moment in terms 
of securing the Sugar Group's corporate assets is at the 2014 Lampung governor election title. (Source: Informant Interview, 2014)

\section{CONCLUSION}

This research focused on SGC and its dynamics in Lampung local politics. The problem in this study is the SGC unwillingness to be interviewed and questioned the grounds are too sensitive and secret of the company. So that this study examines the theories of capitalism wrapped by corporations and secondary literature studies from the results of other studies.

Need to conduct further research involving a larger respondents in quantitative frame in order to see the public perception of the SGC's involvement in local politics Lampung especially in gubernatorial and local elections December 2015. Simultaneously being challenge the author to do so in next study.

While the authors conclude that the SGC relationship in Lampung lcal election in 2014 is very thick in the pair Ridho and Bachtiar, by moving company money to buy some voters (vote buying) with fantastic campaign programs. Example; puppet wrapped with prizes are very attractive, motorcycle gifts and luxury items other. The findings of the division of sugar in several places even though it cannot be proven in Gakkumdu. Various reports gathered by the Supervisory Committee denounces atan and Regency / City always just raw in Gakkumdu due to the loss of evidence.

The advantage gained by SGC in the context of the Lampung local election was the resolution of the problem of leasing land in Lampung Province for the development of the company, without having to pay higher costs because the regional leadership in Lampung was already in the company circle.

\section{REFERENCES}

Aspinall, Edward. (2013) 'Victory of Capital', Prism. 32 (1), pp. 20-34.

Barenscoot and Purba (2014) accessed May 25, 2014 from http://www.insideindonesia.org/pe milu-lampung-yang-lapis-gula

Budiarjo, Miriam. (2008) Basics of Political Science. PT Gramedia Main Library : Jakarta

Choirudin, Achmad. (2013) 'Indonesian Capitalism at the Crossroads', Prism. 32 (1), pp. 121-129.

Government Regulation No. 40 of 1996 on leasehold, Right to Bang unan, and Right of Use of Land

Hadiz, Vedi. (2013) 'The Rise of Capital', Prism. 32 (1), pp. 3-19.

Hiariej, Eric. (2003) 'Marxist State Theory', Journal of Social and Political Sciences. 7(2), pp. 261-282.

Hiariej, Eric. (2006) 'Development of State Capitalism in Indonesia', Journal of Social and Political Sciences, 10(2), pp. 91-120.

Indonesia, R., 2004. Undang-Undang Republik Indonesia Nomor 32 Tahun 2004 Tentang Pemerintahan Daerah. Jakarta (ID): RI.

Indonesia, R., 2004. Undang-Undang Republik Indonesia Nomor 32 Tahun 2004 Tentang Pemerintahan Daerah. Jakarta (ID): RI.

Indonesia, P.R. and Indonesia, P.R., 196o. Undangundang No. 5 Tahun 196o Tentang Peraturan Dasar Pokok-pokok Agraria. Ganung Lawu.

McIntyre, Andrew. (2007) Indonesia: Democracy and The Promise of Good Governance. Institute of Southeast Asian Studies: Singapore .

Miles, Mattew B and AM, Huberman. (1992) Qualitative Data Analysis. University of Indonesia Press. Jakarta.

Neuman, Lawrence. (2006) Social Research Methods. University of Wisconsin at Whitewater: USA

Pratikno (2005) 'Good Governance and Governability', Journal of Social and Political Sciences. 8 (3), pp. 231-248. 